\title{
DEN SAGLIGE IDEOLOGI
}

\section{Peter Søndergård}

\author{
"Dem være pris, \\ dem være held, \\ dem være tak og ære, \\ en skål for dem, \\ der ej gør spræl, \\ men er, hvad de skal være." \\ Erik Bøgh, 1862 .
}

Ved en analyse af universitetsforhold og af de handlinger, der udspringer af disse forhold bør udgangspunktet være, at universitetet opfattes som en del i en samfundsmæssig totalitet og følgeligt ikke kan betragtes isoleret. En analyse af universitetsproblematikken må med andre ord tage udgangspunkt i den samfundsmæssige virkelighed, som den er beskaffet af materielle og immaterielle tilstande.

\footnotetext{
Ved analyse af samfundsforhold har den af Karl Marx udviklede historiske materialisme været tolket således, at den mest frugtbare indgang til en forståelse af samfundsdynamikken er en analyse af de materielle forholds kvantitative og kvalitative aspekter efter dialektiske principper, mens de immaterielle eller ideologiske tilstande tænkes afledt eller bestemt af de materielle forhold. Dette åbner mulighed for en isoleret analyse af den materielle virkelighed, mens en analyse af den ideologiske virkelighed ikke lader sig isolere fra det materielle. Denne tolkning af den
}

historiske materialisme kan kaldes den dogmatiske eller teknologiske alt efter temperamentet.

Uden her at komme nærmere ind på indholdet af den historiske materialisme kan det derfor synes urimeligt at denne artikel behandler et emne indenfor den samfundsmæssige virkelighed, eller den del af den samfundsmæssige virkelighed, som kan kaldes den ideologiske, en behandling, som kun få steder, og da kun i grove træk, vil trække den materielle virkelighed ind $i$ analysen.

Dette emne er politikken eller en del heraf - uddannelsespolitikken - eller 
nærmere det konservative erhvervspartis uddannelsespolitik, som iøvrigt ikke adskiller sig nævneværdigt fra de andre partiers uddannelsespolitik, når undtages VS og til dels SF. Gennemgangen vil kun få steder hæfte sig ved de generelle eller filosofiske sider af politikken, men i stedet være formet som politiske kommentarer til uddannelsespolitiske udtalelser, som de formuleredes for godt to måneder siden af en af dansk retoriks banale elementer politikeren Knud Bro.

Når dette emne alligevel tages op, skyldes det, at det ud fra flere forhold kan begrundes at betragte et politisk hoveds ideologiske tilstand Helt bortset fra at analyseprincipperne m.v. i den historiske materielisme kan betragtes som sagen uvedkommende, og at man derfor blot behøver at "kile på" med analysen uden at søge denne integreret $i$ et større perspektiv, skal det blot nævnes, at flere nymarxister hævder, at en forstålse af samfundsdynamikken ikke alene erhverves ud fra en analyse af de materielle forhold i den ideologiske overbygning og således også af politiske forhold som f.eks. magt og beslutningsforhold/ beslutningsrelationer.

Hvis denne antagelse er rimelig, vil det sige, at det kan forsvares at analysere politikken som værende et af de elementer, som skaber historien og at det historiske $i$ det mindste ikke altid forklares ved lutter materielle forhold. Hermed er det ikke sagt, at politikken kan betragtes som isoleret fra den materielle virkelighed, blot at man tildeler politikken en mere selvstændig stilling end den marxistiske tradition indtil for få år siden var tilbøjelig til.

$\mathrm{Nu}$ er det ikke politikken som sådan der har interesse her, men i højere grad resultatet af de politiske relationer, som de afspejler sig i politiske handlinger og politiske ytringer. Og det sker naturligvis ikke $i$ et tomrum, men i et samfund - det kapitalistiske Danmark, hvilket betyder, at de politiske handlinger og ytringer tildeles en hierakisk vægt, som enten er foreskrevet af loven, og hvor den ikke dækker, af kapitalens fordeling.

Det vil igen betyde, at alle politiske handlinger og ytringer ikke $i$ samme omfang er lige samfundsdynamiske - ja, nogen - det vil sige de fleste - er uden betydning, så længe de er lovlige og ikke truer samfundsmagten. Det vil f.eks. sige, at dine og mine politiske handlinger er yderst tvivlsomme for ikke at sige latterlige. Der er en skærende kontrast mellem at tage sine handlinger og kontroversielle politiske anskuelser alvorligt og benyttelsen af de lovlige kanaler. De lader sig ikke sammenføje, med mindre det kontroversielle lader sig indpasse $i$ den bestående orden. Det skulle ikke være nødvendigt at nævne eksempler på, hvorledes det er gået godtroende samfundsændrere i den parlamentariske møntvask - en møntvask, som de nu må forsvare for ikke at miste en tilkæmpet personlig magt og prestige. Blot er der måske at tilføje, at vi gør de arme mennesker en bjørnetjeneste ved at stemme hvert fjerde år, for ved at holde dem til parlamentet, forhindrer vi dem $i$ at se sig selv som lænkehunde, hvor kæden godt nok er af guld, men uomsættelig; forhindrer dem $i$ at pleje de erhvervede fysiske og psykiske forstyrrelser - hør blot på Poul Møller og Morten Lange - for ikke at sige at se på dem (det er alvorligt ment) o.s.v.. For ikke at tale om dig selv som vælger eller arbejdskraft. Du er nemlig ikke eller betragtes ikke som et menneske, men som en offentlig mening eller produktionsenhed, helt bortset fra, at du er til grin hvert fjerde år.

Anderledes forholder det sig med erhvervenes og statens politik, som synes at blive mere og mere overensstemmende. Det er $i$ disse lag politikken er samfundsdynamisk, d.v.s. hvor politikkens målsætning skabes.

Det er i disse lag, politik påståes at være det muliges kunst, samtidig med at man patenterer det muliges definition; en definition, som altid synes at være uløseligt bundet til det monopolkapitalistiske industrisamfunds præmisser. I dette samfund er teknik og videnskab ved at blive en af de vigtigste produktivkræfter, og politikken, den moderne politik, er derfor $i$ høj grad rettet mod uddannelsesinstitutionerne.

Videnskaben kommer i kraft af at være en produktivkraft til at spille 
en politisk rolle, idet den faktisk tjener politiske interesser. Det er derfor berettiget at rette kritik mod den type filosofi og samfundsvidenskab, som bidrager til at opretholde troen på en skarp adskillelse af videnskab og politik. En sådan trosfunktion er $i$ virkeligheden af samfundsbevarende karakter, men vanskelig at kritisere, fordi den skjuler sig bag saglighedens ideologi $i$ form af ekspertkomitéer og lignende.

Det er som fortaler for denne saglighedens ideologi og i kraft af sin placering $i$ de beslutningsrelationer der vedrører uddannelse, at politikeren Knud Bro har interesse - ikke som person, men gennem sine politiske udtalelser. Udtalelser, som tager sigte på en ændring af forholdene omkring universiteterne.

Imidlertid sker der løbende ændringer af disse forhold, blot har ændringerne indtil nu haft karakter af kapacitetsændringer, d.v.s. ændringer i det kvantitative aspekt: større studentertilgang, vækst $i$ administra tionsbureaukratiet, større mængder af empirisk forskning etc. Anderledes forholder det sig med de kvalitative ændringer: universitetsadgangen er stadig forbeholdt de $i$ forvejen uddannelsesmæssigt priviligerede grupper, og det er umuligt at spore nogle rekrutteringsmæssige ændringer; administrationsbureaukratiet kører stadig iført uoverskuelighed, træghed, studenteraversion og hierakisk ineffektivitet så godt som uantastet videre. Kun har studenterne fået eller får visse udemokratiske og utilfredsstillende indrømmelser $i$ form af repræsentation $i$ administrationshierakiet og først og fremmest $i$ dets nederste lag; forholdene omkring den videnskabelige forskning styres stadig på totalitær vis, og resultatet er alt for ofte steriliserede og fantasiforladte forskningsprojekter.

En af årsagerne til dette videnskabelige niveau skal søges i den positivistiske videnskabstraditions eneherredømme: dens udøvere indtager en autoritær og selvtilstrækkelig holdning og undlader helt at lade sig inspirere af andre videnskabsideologier, med en deraf følgende indavl i positivistisk tænkemåde. Dette er forhold som gør sig gældende først og fremmest, men ikke alene inden for det samfundsvidenskabelige felt, hvor enhver fundamental kritisk samfundsanalyse afvises som uvidenskabeliq.

Men ukritisk og uvidenskabelig er netop en disciplin, hvis fornemste opgave tidligere var en reaktion på den religiøse dominering af videnskaben $i$ det syttende og attende århundrede, men som nu er blevet et middel til kontrol af samfundets medlemmer.

Som det er nu er samfundet "slået af systemtvang som ytrer sig som en total mobilisering mod fjender i systemet, udaf såvel som indaf. Denne systemtvang ytrer sig som en stræben efter at få alle samfundsmedlemmernes interesser til at falde sammen. dette betinger bl.a. en teknologiseret og total administrativ kontrol for at planlægge og kontrollere det økonomiske liv. Denne ekspanderende administration former sin egen for forskning efter sit eget funktionelle forbillede: behandlingen af begreber antager en bestemt politisk funktion, at tjene tilpasningen til det bestående samfund. Denne forskning fremstår som empirisk operationalisme ( $i$ en positivistisk forskningsproces -p.s.), men resulterer $i$ bedre metoder for social kontrol: den metodologiske oversættelse af universelle begreber bliver da en undertrykkende reduktion $i$ tænkningen. I kraft af sin metodologi er denne empirisme ideologisk". ${ }^{11}$

Men ikke alene er denne empirisme ideologisk; universitetet bliver selv ved med at være indoktrineringsinstitut for denne ukrtiske empiri ideologisk. Eller for at bruge et værdiladet begreb: universitetet bliver et led i klassekampen; med de mægtige og mod de magtesløse, med de undertrykkende og mod de undertrykte.

Det er $i$ dette lys kampen om universitetet skal ses. Og det er $i$ dette lys Knud Bros uddannelsespolitiske udtalelser skal analyseres. Den Knud Bro som siger: ... "at man har et berettiget krav på at være med til at

1) John Lundstøl: "Vitenskabelighet og dumhet" - PAX, nr. 191, Oslo 1969. 
påvirke de evner, som folk faktisk har brug for, når de skal arbejde $i$ erhvervslivet eller samfundslivet".

(Dette citat såvel som de øvrige Bro citater er fra folketinget uddannelsesdebat den 3.12 - 1969. Drøftelser af universitetsuddannelsen skulle formelt ikke behandles ved den lejlighed, men specielt Bro beskæftigede sig ofte med universitetsforhold i sit indlæg.)

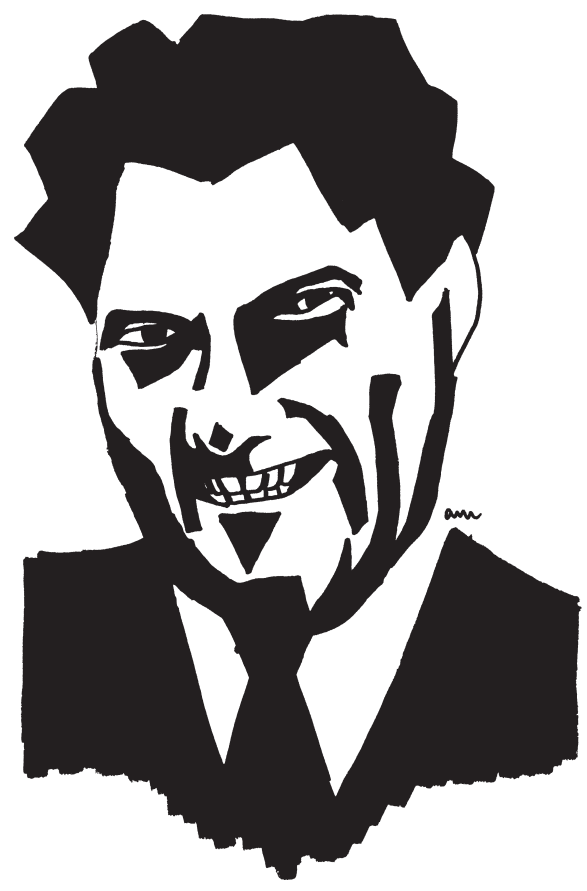

Knud Bro om videnskab:

"Til syvende og sidst er videnskab lærdommens moder, og det gælder for uddannelse, som det gælder for videnskab, at i samme grad som videnskaben er højreorienteret eller venstreorienteret er den ikke videnskab, og $i$ samme grad som den er videnskab er den ikke højreorienteret eller venstreorienteret."

(Knud Bro, Folketinget, d.3-12-1969.)

Det er karakteristisk for dette som for de efterfølgende Bro citater, at det er vanskeligt helt at fatte indholdet, netop fordi de ord som anvendes har mange følelsesmæssige aspekter. Det gælder ikke mindst ord som "højreorienteret" og "venstreorienteret". Men at ordene dækker negativitet og usaglighed er klart nok meningen, sålænge det gælder videnskab.
Indirekte ligger der $i$ det at være "orienteret" bestemte værdisæt. F.eks. har Knud Bro som højreorienteret eller midtpunktsøgende person et værdisæt, som f.eks. adskiller sig fra det værdisæt KURASJES redaktion har.

Bros værdisæt er opbygget af mange faktorer, men vigtigst er det nok, at han som repræsentant for magthaverne, har visse interesser, sine egne eller erhvervslivets, som skal dyrkes for at magten ikke skal mistes. Bro må derfor lægge sig tæt op ad sin politiske referensramme, det konservative erhvervsparti, hvis blå drenge i den senere tid har haft stærk medvind $i$ partiet (der henvises til avisreferater fra det sidste konservative landsmøde). Omvendt har forståelsen af Bro som lænkehund, menneskers generelle afmagt og årsagerne hertil produceret værdisæt hos mange mennesker, som hvis Bros betegnelse skal anvendes, kan kaldes venstreorienterede. Og det er denne generelle orientering, som er tidsskriftets linie.

Så alngt så vidt - og Knud Bro vil måske bemærke, at det er beklageligt, hvis danske borgere har personlige og helt private værdisæt, som man i saglighedens interesse kan kalde abnorme, men det er der desværre ikke noget at gøre ved, i det mindste ikke så længe orienteringen ytres på lovlig vis.

Men med videnskab er det anderledes, for den skal, siger BRO, for at være videnskab være værdifri, dvs. at forskningsresultater skal være foruden forskerens og forskningsprocessens værdier. I og for sig er dette en ret besynderlig udtalelse at fremkomme med $i$ folketinget. Hvilke forhold kan have motiveret denne udtalelse og netop nu. Har videnskaben af de overfladiske, og de $i$ hvis interesse dogmet plejes, ikke altid været betragtet som værdifri, og hvad er så hensigten med at slå det fast med lysmaster. Den slags udtalelser er vist ikke før hørt i folketinget. Hvorfor denne ivrighed? Hvorfor netop nu? Hvad er Knud Bros motiver?

$\mathrm{Nu}$ er en ting som videnskabernes værdifrihed en sag, som optager og, som 
har har optaget kritiske studenter gennem længere tid; og ved analyser og dialog har den opfattelse, at der ikke gives nogen værdifri videnskab fået stærkt fodfæste. Måske er Knud Bro bekendt med dette fodfæste og foruroliget over konsekvenserne af denne indsigt hos studenterne og en del lærere.

Denne indsigt er fremkommet ve analyser inden for specialt tre områder: 1) analyse af de historiske betingelser for det positivistiske videnskabsideals opståen.

2) analyse af dette videnskabsideals ideologiske (værdimæssige) indhold, såvel de forhold som er overladt til den enkelte forsker at tage stilling til; valg af problemområde og forskningsprojekt, vurdering af de videnskabelige resultater og ved teorikonstruktioner, som af de værdier, der implicit findes i forskningsprocessen, specielt adskillelsen mellem fakta og teori.

3) analyse af det positivistiske videnskabsideals samfundsmæssige funktion, både hvad angår anvendelsen af forskningsresultater, og hvad angår anvendelsen af højt uddannet personel.

Og det gælder for alle tre forhold, at de må analyseres i lyset af samspillet mellem videnskabsideal på den ene side og det samfundsideal, som er udtrykt $i$ den dominerende politiske filosofi (den legitime ideologiske opfattelse af den samfundsmæssige virkelighed) på den anden side.

Og Knud Bro og de andre lænkehunde har god grund til at være foruroligede. For analyserne går hånd $i$ hånd med kravet om studenterindflydelse på forskningen, en demokratisering som blot ville have været en liberal reform, hvis studenterne havde accepteret det rådende videnskabsideal og dermed den herskende samfundsform. Men sådan er det ikke.

Analyserne inden for de tre nævnte hovedgrupper skal ses som et led $i$ den globale frigørelsesproces, som studenternes famlende, men stadig mere bevidste bidrag til en global dynamik, der næres af de kapitalistiske samfunds ondskab og menneskeforagt. Vi må påvise at den "objektive videnskab", som Bro er fortaler for, og som i virkeligheden bygger på det positivistiske videnskabsideal, understøtter det kapitalistiske samfund, først og fremmest fordi den positisvistiske tradition ikke åbner mulighed for samfundskritisk holdning, og slige "metafysiske" tilbøjeligheder, og fordi positivismen har udviklet sig til at blive en a-historisk videnskabsideologi.

Nu kan det ikke undre, at Bro understøtter det han tjener sine penge og prestige på, for det er en udbredt parlamentarisk erhvervssygdom, men man kan angribe ham for en vildledende argumentering, som enten er udtryk for hans naive psykedeliske verden, eller - og det er snarere tilfældet en bevidst forplumring af de faktiske tilstande. Til denne forplumringskategori hører hans bemærkninger om "objektiv videnskab". Den objektive videnskab som holder yderst hemmelige møder på Marienborg osv.

Kære Knud Bro:

I din egenskab af udemokrat og officiel fortier, gør du dig til en af systemets mest grundige røvslikkere. Men vi er dig taknemmelig for at du som eksempel ikke lægger skjul på din etiske korrupthed, for netop derved virker du afskrækkende, og netop derved kan du blive et led $i$ vores egen frigørelse.

Frigørelsen må tage sit udgangspunkt $i$, at vi indser det relative $i$ vor situation. At vi ikke som den positivistiske videnskab opfatter os som ahistoriske individer, men at vi som menneskelige væsener er produkter af et historisk forløb samtidig med, at vi skaber historien. At vi opfatter en Bro som et historisk fænomen, som en relativitet, som en tidsbegrænset gestalt. At vi opfatter det en Bro repræsenterer som et historisk fænomen, som en tidsbegrænset samfundsog produktionsform, der $i$ sine sidste faser bliver et historisk paradoks.

Og frigørelse og selvforståelse står $i$ et dialektisk forhold til hinanden. "Kend dig selv !", sagde Sokrates. "At kende sig selv er et skridt på vejen til frigørelse. At kende sig selv hjælper en $i$ at kontrollere sig selv. Man bliver klar over, hvad der binder. Hvis dette er rigtigt, så er selverken- 
delse ikke først og fremmest noget som har værdi "i sig selv" - den har værdi fordi den er et redskab til noget." 2)

Selvforståelsen må tage udgangspunkt $i$ at vi indser det relative $i$ vor situation. At der i vores selvforståelse indgår et vist historisk element. At vor forståelse af en situation delvist tager udgangspunkt i tidligere oplevede situationer.

Lad os søge vores situationsforståelsers historiske afhængighed anskueliggjort ved nogle eksempler, hvor det historiske element fremtræder som en totalitet og ikke et forløb, som det nødvendigvis må være for at situationsforståelsen kan blive korrekt

\section{Eksempel 1.}

Ordet arbejdsløshed vil for de fleste mennesker $i$ tresårsalderen og derover være uløseligt knyttet til den situation de gennemlevede $i$ trediverne, og de vil derfor være tilbøjelige til at bedømme situationen $i$ dag positivt eller negativt afhængigt af arbejdsløshedens størrelse, selv om dette begreb vel ikke kan siges, at være en væsentlig indgang til forståelse af, hvorledes samfundet fungerer i dag om samfundet er godt eller ondt. De $i$ trediverne arbejdsløse har måske derfor vanskeligt ved at se det berettigede $i$ den samfundskritik, som bl.a. udgår fra studenterne.

\section{Eksempel 2 .}

Ordet frihed er i mange menneskers bevidsthed associeret med datoen den 9. april 1940. Fra dette tidspunkt og $i$ de følgende fem år var en væsentlig del af den daglige oplevelse, oplevelsen af åben vold og tvang. Frihed defineres af de samme mennesker i dag derfor ved fravær af åben vold og tvang. Som $i$ det foregående eksempel hindrer denne situationsoplevelse mange mennesker $i$ at se det meningsfulde $i$ kritik, som hævder, at det danske samfund er ufrit, både som samfund og for en befolkning, der udsættes for legitim vold og arbejdstvang. (For en ordens skyld - den samme ufrihed gør sig uden tvivl også

2) Helge Høibraaten: "Filosofi og Frigjøring", PAX, nr. 191, Oslo 1969. gældende $i$ en række socialistiske samfund, men det kan aldrig blive et forsvar for den danske statsvold).

Som det gerne skulle fremgå af disse eksempler, mister vi information om den samfundsmæssige virkelighed, når det historiske element $i$ vor forståelse fremstår som en absolut størrelse og ikke som et forløb. Sroget har her en vigtig funktion. Sprog og situation hører nøje sammen. Således kan den kolde krigs terminologi ikke frigøres fra den kolde krig, et forhold som de altdominerende borgerlige massemedier udnytter $i$ egen interesse. Man behøver blot at betegne samfundskritik som "kommunistpropaganda", "totalitær tænkning" osv., behøver blot børste støvet af en gemt og kun halvt glemt situationsterminologi, så bliver mennesker rådvilde og holder sig til den sikre afmagt.

Det er denne historiske absolutisme, som er en vigtig bestanddel af den saglige ideologi og som er det filosofiske udtryk for samfundssystemets selvopretholdelsesdrift. Det er den historiske absolutismes filosofi, som inddoktrinerer opfattelsen af, at de fundamentale træk i det kapitalistiske samfund er gode og endelige. At dette samfund er slutstenen $i$ den menneskelige udvikling og derfor må værnes mod konspiratoriske anslag indbildte eller virkelige.

Den historiske absolutisme er mistænksom, i få menneskers interesse. Betegnende for den historiske absolutisme er dens gennemtrængen af alle samfundslivets aspekter. Den historiske absolutisme er borgerskabets bedste indoktrineringsmedicin til at holde kæften lukket på det tavse flertal, som billedlig talt vrider sig under en knebling, der bliver stadig mere brutal. Den historiske absolutisme vender sig imod relativ tænkning, fordi denne er kættersk og farlig, fordi den genopliver en solidarisk humanisme, fordi den er en negation af onde tilstande, fordi den er solidarisk med de undertrykte og afmægtige, fordi den afslører blodsugerne og deres ynkelige spytslikkere. Den historiske absolutisme er fordummende, nationalistisk, fascistisk, stationær, reaktionær, krigsliderlig, imperialistisk, raci- 
stisk, mistænkeliggørende, autoritetstro, børnefjendsk, pervers og ond. Den historiske absolutisme er sagligt borgerlig; den er Bro, Helge, Thestrup, Møller, Haunstrup, og alt det de repræsenterer.

Frigørelsen er relativ for at blive absolut, men det absolutte er relativt.

Det positivistiske videnskabsideal er et relativt ideal, og et ideal som er udsprunget af en bestemt historisk situation, men det positivistiske videnskabsideal indoktrineres som en absolut historisk størrelse. Lad os frigøre os ved at betragte idealets historiske betingethed:

"Ideen om sandhedens eller kundskabens værdi "i sig selv" blev i renæssancen brugt som forsvar i mod dem som ville lade religionen dominere på videnskabens bekostning. Ideen om sandhedens værdi i sig selv blev altså brugt til at nå visse værdier den blev en del af borgerskabets kamp mod de traditionelle autoriteter. Men dette blev ikke teoretisk reflekteret. Renæssancefilosoffen Bacon havde alligevel en vis forståelse af teoretisk kundskabs forhold til praksis: for Bacon var kundskab lig med magt, og magt et redskab til frigørelse, frigørelse fra materiel nød - og dette var en forstålse af frigørelse, som var lige så vigtig som frigørelsen fra de traditionelle åndsmonopoler.

I renæssancen virkede altså både ideen om al kundskabs værdi i sig selv og ideen om at kundskab skal bruges til noget frigørende. Sammen udgør de $i$ dag den positivistiske (empiriske) videnskabs selvforståelse. Som videnskab ser denne videnskab sig selv som værdifri, dens eneste videnskabelige værdi er, ikke at have nogen værdier, men at søge kundskab for kundskabens egen skyld, indse kundskabens værdi i sig selv.

Som politisk projekt taler denne videnskab om tekniske opfindelser, om effektivisering af den samfundsmæssige produktion, frihed fra materiel nød. I dag ser vi, at skellet mellem videnskab og politik, mellem teori og praksis er ved at nedbrydes til sin kerne. I dag fungerer ideen om værdifri videnskab som ideologisk maskering for en samfundsmæssig proces, som er $i$ færd med at rasere alle vore traditionelle værdier. Den gør videnskabsmænd til teknikere, som løser spørgsmål om midler og som distancerer sig fra målspørgsmål med den undskyldning at de ikke er politikere - $i$ et samfund hvor den kritiske politiske debat er på vej til at uddø, og hvor alt som kan påklistres etiketten videnskab tenderer til at blive ukritisk accepteret $i$ det politiske liv.

Ideen om den værdifri videnskab fungerede progressivt $i$ kampen mod middelalderens kirke og fascismens åbne antividenskabelighed; i dag legitimerer den en proces, som nedbryder den debat som den tidligere bidrog til at skabe. Har vi forstået dette, da har vi forstået positivistisk videnskabsfilosofis relative historiske betydning, en historisk refleksion har frigjort os fra positivismens tankefængsel.

At beskrive historiske forandringer er bl.a. at beskrive sådanne forandringer i selvforståelsen. Idet vi beskriver sådanne historiske situationer, dvs. bevidst retter opmærksomheden mod dem, forandrer vi vor forståelse af vor egen situation. Og omvendt: Vi forstår tidligere historiske situationer bedre med udgangspunkt $i$ vor egen situation: forstår vi hvorfor de fleste danskeres frihedsbegreb er inadekvat i dag, så forstår vi bedre dets relevans $i 1940$.

Dette er et aspekt af hvad historisk dialektik er for noget - jo bedre vi forstår os selv, jo bedre forstår vi fortiden, og omvendt." 3)

Kan studenter og lærere for denne videnskabsideologis ensidighed og dens indoktrinerende funktion på universitetsuddannelsen, da vil universiteterne ikke kunne bidrage med de til det kapitalistiske samfunds opretholdelse nødvendige eksperter og manipulatorer som fx.:
a) personel til administrering af klassestaten (jurister, social- økonomer m.fl.)
b) højt kvalificerede fagfolk som driver industri og krigsforskning,

3) Høibraaten - op. cit. 
og som bliver stadig vigtigere for udviklingen af produktivkræfterne.

c) eksperter til industrien som har til opgave at tilsløre for arbejderne, at de bliver udbyttet for derigennem at sætte arbejdsproduktiviteten op (industrisociologer, industripsykologer $\mathrm{m}$. fl.)

d) planlægningseksperter, hvis opgave det er at lægge de materielle rammer for produktionen og en produktionsform som er umenneskelig og afmagtsskabende.

e) socialeksperter hvis opgave det er at "glatte ud" på de manifeste sociale og psykologiske menneskelige ulykker, som er skabt i et modsætningsfyldt samfund.

f) den borgerlige ideologis eksperter, eksperter som er uddannet indenfor de filologiske, historiske og filosofiske discipliner. ${ }^{4)}$

Kan og vil studenterne unddrage sig spillet på dette absurde teater og $i$ stedet angribe det kritisk, forståeligt og fundamentalt såvel i teori som i praksis, da vil en sådan unddragelse $i$ langt højere grad end isolerede reformer som $\mathrm{fx}$. "åbent universitet", "studenterdemokrati", osv. være en trussel mod den kunstigt opretholdte ro og orden og en solidaritetserklæring til de afmægtige.

Og så lad blot Gud være med de saglige, hvis historien er med os.

Det, der med andre ord er nødvendigt, er en politisering af universitetet.

Knud Bro om politisering:

"Lad mig sige det helt præcist: vi ønsker politik i folkeskolen, vi ønsker politik i gymnasiet, vi ønsker politik på universiteterne - hvis man dermed forstår, at man optages af politik, drøfter politik. Men vi ønsker ikke en politiserende skole, vi ønsker ikke agitation, men kundskaber og samtale og vi ønsker, at der ud af det skal komme mennesker og

4) Eksemplerne: a), b), c) og f) er lånt fra Stein Rafoss: "10 teser om vitenskap, universitet og revolusjon" - PAX, nr. 191, Oslo 1969. ikke agitatorer." (Bro, Folketinget, 3.12 .1969 )

Imidlertid fremgår det ikke klart af det citerede og ej heller af hvad Bro $i$ øvrigt sagde under uddannelsesdebatten i folketinget, hvad der menes med begreberne "politik" og "politisering". Men at politik er positivt og politisering negativt er klart nok meningen - for slet ikke at tale om politiserende agitator - ildtang !

Han er nu sød ham Bro - se blot hvorledes han søger at mistænkeliggøre en bestemt gruppe studenter ved at anvende en række negativt værdiladede ord, uden nogen definering og nærmere forklaring.

Dette er insinuationens og mistænkeliggørelsens politik.

Men måske betyder det at drøfte politik, at man debatterer indenfor det rådende samfundssystems rammer, mens politisering så betyder, at man ønsker at nedbryde disse rammer. Politisk drøftelse er da lig med saglig drøftelse fordi rammerne pr. definition er saglige. Den saglige ideologi er derfor den ideologi, som rammerne afstikker.

$\mathrm{Nu}$ karakteriseres "rammerne" omkring det danske samfund forskelligt alt efter hvem der karakteriserer dem. Således karakteriserer liberalisterne rammerne ved: demokrati, frihed, respekt for den enkelte, folkeoplysning m.v., mens socialister, kommunister og anarkister betegner samfundets rammer som: kapitalistiske - kun få mennnesker har den reele magt, ufrie - kun frihed for de få, udbytning af den enkelte - deportationslov, afdragshandel, arbejdsløshed ect., manipulation og indoktrinering mv.

Sjovt nok synes socialister, at de lige nævnte liberalistiske slagord (for de er i højere grad slagord end udtryk for faktiske tilstande) er gode, ja, endog så gode at en opmærksom liberal kan finde dem gentaget overalt i socialistisk litteratur, men vel at mærke sat ind $i$ en sådan sammenhæng, at et samfund karakteriseret ved disse ord ikke får det kapitalistiske samfunds uhyrlige følgevirkninger. 
Dette gode samfund er det socialistiske, men som tidligere nævnt, tror vi ikke, at det kan skabes ved politisk arbejde igennem liberalisternes demokratiske kanaler, dertil er de afskrækkende eksempler for mange. En ærlig socialistisk politik må derfor søge at nedbryde de eksisterende politiske kanaler, og derigennem samfundets rammer.

En ærlig socialistisk politik må være politiserende og modsætningsafslørende. Men hvorledes politiserer vi universiteterne ?

"... Jeg tænker særlig på hvordan universitetet som institution $i$ vort samfund, hvor teknik og videnskab måske kan siges at være blevet den vigtigste produktivkraft på en ideologisk måde legitimerer bestemte magtinteresser overfor masserne. I kraft af denne funktion bliver der en række centrer $i$ universitetet som $i$ særlig grad modvirker en almindelig politisering. Uden at disse centrer analyseres og angribes praktisk ud fra sin magtformidlende funktion, vil politiseringen løbe ud i sandet. Gennem disse centrer udøver erhvervsliv og stat et stigende kontrolpres overfor universitetet som helhed, overfor både lærere og studenter. Hvilke organer er det så, jeg har i tankerne? Jeg tænker på pensum og undervisnings oplæg, på eksamensformer og karaktersystem, på de faglige og kompetenceorienterede bureaukratiske skillelinier mellem studenter og lærere, og ikke mindst på de bevidste og ubevidste idealer, som gennemsyrer hele institutionen og finder det klareste udtryk i de metodologiske krav. Politisering af universitetet vil sige at bevidstgøre disse organer som funktionelle faktorer $i$ udøvelsen af den rådende ideologi og de herskende magtinteresser. Det vil videre sige kritik af disse instanser, fordi de hindrer politiseringen og demokratiseringen af universitetet. Denne kritik må konkretisere sig i praktisk politik, som tager hensyn til institutionens egenart. Den må tage fat samtidigt $i$ teori og praksis, f.eks. ved at drive alternativ faglig praksis indenfor universitetets egen ramme, bl.a. som studenterseminarer, og ved at koor- dinere de demokratiske og politiske kræfter særligt i studentermassen og blandt yngre lærere og forskere $i$ forsøgene på at forandre allle disse organer for formidling af samfundsmæssig magtudøvelse.

Som Habermas fremhæver behøver denne politisering ikke at stå $i$ vejen for det samfundsmæssige arbejde. ... Men målet må være at gøre universitetet som institution og menneskene som virker der, selvstændige til at kunne blive en kraft $i$ en forandrende politisk praksis." 5)

Men siger Bro så længe man enten går i skole, i gymnasiet eller på universitetet må man kun drøfte rammers politik - selv om rammerne er så vide, at du roligt kan kalde en Helge Larsen for en skid, for en ko, for en bonde, for en so. Larsen vil nøjes med at flytte sig på taburetten, Bro vil være ligeglad og folk vil synes, at du har langt hår og er tåbelig. Og det er du også, fordi du er ufarlig.

Men hvis du næste torsdag lader dig tage imod hos Helge Larsen og hvis han ikke er til møde med erhvervslivet på Marienborg, og du da f.eks. spørger ham, hvad han mener om demokrati og frihed såvel i samfundet som på universitetet, så vil han bede dig gentage ordene og dernæst enten bede dig om at skride eller henvise dig til Thestrup. Hvis du er så forudseende, at du i forvejen har allieret dig med 200 andre og I efter tur stiller samme spørgsmål, og hvis I er 400 den følgende torsdag og 800 torsdagen igen osv., så vil Larsen og Thestrup begynde at mure dørene til og den 10'ende torsdag vil de barrikadere sig i Christiansborg.

Folk vil da begynde at synes, at politikerne er underlige, og de vil begynde at lytte til dig, når du fortæller, hvad du mener med demokrati og frihed. For det vidste du selvfølgelig godt i forvejen.

Og så er Bro ikke ligeglad mere. Han vil rejse riget rundt og mane folket til fornuft, men det går langsomt,

5) John Lundstøl op.cit. 
for folket gider ikke komme til hans møder, og Bro er derfor henvist til personlige møder ved køkkendøren.

Der er så to muligheder: Enten vil han blive fascineret af folkets skikke: den måde konerne kysser mændene på og omvendt, deres madlavning, deres sammenkomster, deres altankasser og stokroser, og forhåbentlig er de også gode ved børnene. Han vil da falde til ro, pleje sit fremadskridende lænkesår, gribe om dets rod og forære $\varnothing \mathrm{k}$ til Cuba, kysse sin kone på en ny måde, så hun sprænger socialdemokratiet og Hækkerup. Med folket i folket.

Eller også er han allerede så stivnet, at han ikke kan se folket for bar vælgere. Men da der ikke er nogen, må han selv skaffe dem. Og det er vanskeligt, for folket har gravet brostenene op og soler sig i sandet.

Men hvad der så vil ske afhænger af modsætningernes art og styrke. Enten bliver en Bro en Hitler, eller også er det begyndelsen til det gode samfund. Virker det udflippet. Nåhh ja. En Bro vil kalde det usagligt.

Knud Bro om eksamen:

"Eksamen opfandt Sokrates, da han gik rundt på gader og stræder og stillede den tids autoriteter de allersimpleste spørgsmål, som så ud til at være lette at besvare, men som de fleste gik i vandet på. Det morede de unge meget, og som Sokrates selv sagde $i$ apologien (forsvarstalen - p.s.): det er også morsomt". (Knud Bro, Folketinget $3 / 12,1969)$.

Helt bortset fra en sproglig mærkværdighed - i virkeligheden står der, at det var eksamen, som opfandt Sokrates - udsagnsled, grundled, kryds og bolle - så er indholdet i dette citat, selv om det ikke siges eksplicit, et forsvar for en bestemt eksamensform, legitimeret ved en filosofs udsagn.

Når Sokrates går ind for eksamen, så kan Knud Bro vel også!

$\mathrm{Nu}$ kunne det være interessant at prøve at forstå Knud Bros utvetydige gåen ind for eksamen som et vigtigt led $i$ uddannelsen, for det er blot 4-5 år siden, at Knud selv for sidste gang var igennem denne pølsemaskine. En begivenhed som der stadig står ry om, og som beredte eksaminatorerne stor fortvivlelse. Men på Det tidspunkt var stud. polit. K. Bro allerede folketingsmand.

Men, hvad det end skyldes - om det er $i$ taknemlighed mod sine gamle lærere, eller om det er krav fra erhvervslivet - så er Bro nu talsmand for de lærer- og professorgrupper, som af ideologiske og økonomiske grunde (det giver en klækkelig ekstraindtægt at være f.eks. censor) er interesseret i en opretholdelse af en forældet eksamensinstitution.

Dette får endda være - værre er det, at Knud Bro for at legitimere eksamen gør vold på historien og tager Sokrates til indtægt for et sæt ideer, som Sokrates intet havde at skaffe med.

Dette skal vi søge at belyse ved et længere uddrag af Per Frederik Christiansens artikel: "Kampen om universitetet" (PAX nr. 191), hvor der er anvendt en såkaldt dialogmodel (Sokrates) til beskrivelse af forsknings- og eksamensinstitutionen:

"... Universitetet er traditionelt strengt hierarkisk opbygget, hvor studenter og "lavere" videnskabeligt personale har lidt eller ingenting at skulle have sagt $i$ de vigtige faglige afgørelser. Dette retfærdiggøres gerne ved et syn på faglig kompetance som det til-grund-liggende $i$ såvel det videnskabelige som det undervisningsmæssige arbejde. Stillingsstrukturen ved universitetet tænkes at afspejle forskernes kvalifikationer; for at sikre fagligt forsvarlige dispositioner bliver det pr. definition uansvarligt af dem $i$ toppen af hierarkiet at overføre myndighed til de, som står lavere.

Dette får til følge et bestemt syn på, hvad videnskab er. Gennem den hierarkiske model tolkes forskning som en slags kvantitativ envejskøring: den som har holdt ud længst og forsket mest, har samlet sig et forråd af videnskabelig tyngde, som giver hans ord social vægt og ham selv embedsmæssig magt til at forme forsknings og undervisningspolitikken inden for hans eget fag. 
Men kan en uhildet sagsrettet forskning vokse $i$ en sådan magtstruktur? Er det ikke tværtimod sådan at videnskabelig opdagelse ikke sker endimensionalt, men i skæringspunktet mellem en formidlet tradition og en søgende fornyelse?

Og dette skæringspunkt træder frem som en dialog, en samtale mellem formidleren af traditionen - den etablerede videnskabsmand - og den som endnu er $i$ sin vorden. Egentlig er selve dialogen formidlingen, og den virker forandrende $i$ to retninger: både på traditionen og på det som er $i$ færd med at opdages. Kun en forståelse af det tidligere skete kan give grundlag for fremskridt, mens ethvert fremskridt stiller det tidligere skete $i$ et nyt lys. Således er det $i$ åndsvidenskaberne og samfundsvidenskaberne - og vel også i naturvidenskaberne.

Det som her ligger til grund er ikke en samling kundskabsdata som mekanisk øges. Det til-grund-liggende er en dialog. Men dialogen lykkes kun når den rent faktisk bliver lagt til grund. De samtalende må underkaste sig og anerkende dialogens strengt saglige forløb, og ikke fordreje dialogens indre retning $i$ kraft af usaglige magtpositioner.

Denne model for videnskabelig forskning er lige så .gammel som den vesterlandske videnskab selv. Den udformes i Platons dialoger og bygger på Sokrates' praksis. Sokrates gik aldrig rundt og forkyndte nogen sandhed. Han gik i samtale med andre mennesker, søgte at opdrage dem ved at stille spørgsmål, således at de selv fandt frem til det standpunkt de fandt var det rigtige - og på baggrund af argumenter som de selv fandt tvingende. Sokrates var kun "anledningen" til at de andre selv fandt frem til et eget standpunkt. Hans kunst er "jordmorkunst". Han er åndelig "jordmor" eller "fødselshjælper" for den andens tanker.

En sådan model for åndelig vækst kan virke $i$ begge retninger. Opdrageren kan selv blive forandret gennem samtalen. Marx synes at være inde på noget $i$ denne retning $i$ sin tredje Feuerbach-tese: "... omstændighederne må forandres af menneskene og ... opdrageren må selv opdrages".
Forudsætningen er her at begge parter anerkender dialogens saglige argumentation som det til grund liggende. Sokrates gik aldrig frem på den måde at han f.eks. sagde til den anden: "jeg har lang træning $i$ argumentation, så du kan lige så godt først som sidst anerkende min opfattelse $i$ denne sag." Eller at han $i$ løbet af samtalen hvis det gik dårligt for ham - skulle sige: "Ja - men husk på de gode argumenter jeg havde forleden dag. Egentlig er jeg vældig god til at argumentere, så du må nok alligevel gi' dig". Når Sokrates får ret, er det netop fordi den anden giver ham ret - eller nærmere: diskussionen giver ham ret.

Et argument om tidligere meritter ville virke pinligt og parodiskt. Men vort universitetssystem bygger på en sådan pinlig parodi: Nøglen til opdragelse af videnskabsmænd er eksamenssystemet.

Og situationen ved eksamensbordet er et symbol på hvordan den videnskabelige formidlings-proces fungerer.

Her foregår der også en dialog, en samtale. Men $i$ dette tilfælde er dialogen ikke selv det til grund liggende. Dialogen er underlagt en ydre social situation, de samtalendes plads $i$ universitetshierarkiet. Den ene part - eksamenskommissionen - kan når som helst træde ud af dialogen, afbryde den og foretage sin vurdering af den andens bidrag til samtalen. Eksamenskommissionen har magt til at fastsætte samtalens konklusion, og denne magt er ikke givet den af den anden part - eksamenskandidaten - og heller ikke af argumentationsforløbet i samtalen.

Derfor er denne dialog ingen virkelig dialog, men en skindialog - et skuespil sat $i$ scene gennem et magthierarki, som ikke er bundet af dialogen. Og fordi dette ydre hierarki ikke hver gang på ny henter sin kraft fra en dialog, fra det sted hvor den videnskabelige formidling mellem tradition og fornyelse foregår, men tværtimod gør denne formidling udialektisk og autoritær, er det uvidenskabeligt og irrationelt.

Men ... når studenterne har rejst krav om reel medbestemmelsesret, er hensigten netop ikke at "tage magten fra lærerne" og sætte studenterne 
på toppen af universitetshierarkiet. Hensigten er tværtimod at frigøre det videnskabelige arbejde fra et uvidenskabeligt og irrationelt magthierarki og erstatte en skindialog med en virkelig, videnskabsformidlende dialog. En sådan frigørelse kan bedst ske ved at de forskellige grupper indenfor hierarkiet bliver repræsenteret på en rimelig, ligelig måde $i$ de organer, som styrer det videnskabelige arbejde."

Og husk næste gang du skal til eksamen, så prøv at få en dialog igang svar på spørgsmålene og stil modspørgsmål. Hold den tilstedeværende "Høgh" eller "Ross" beskæftiget med at tænke, og ikke som de plejer med at manipulere. Kun hvis de er helt umedgørlige, skal du skrue bissen på.

\section{NYT FRA PAX-FORLAG :}

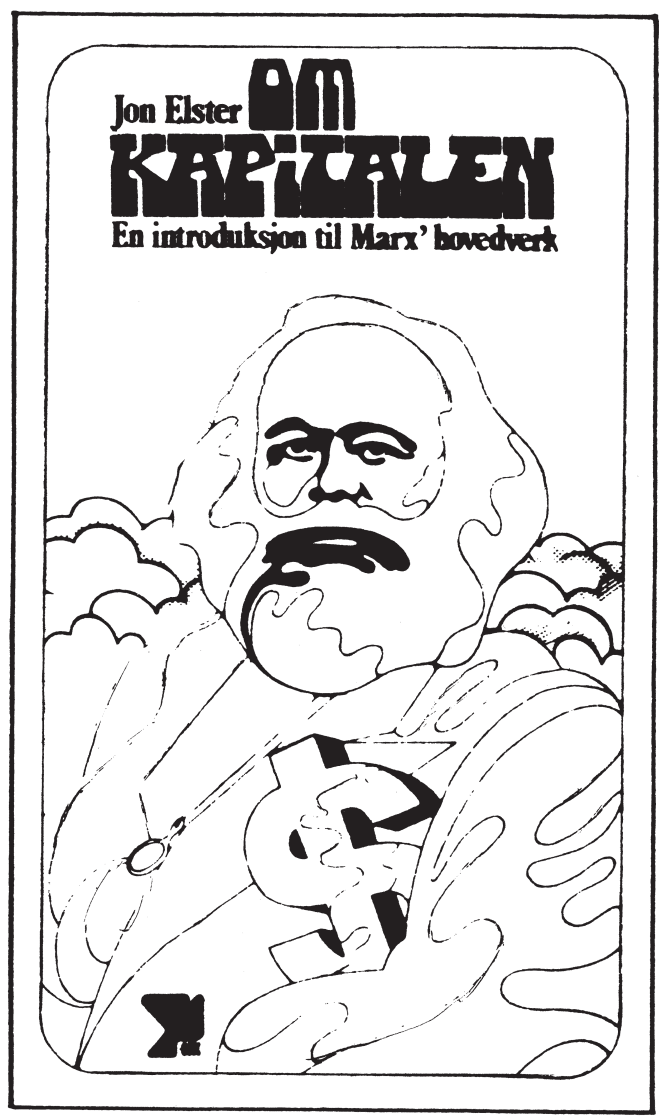

201. Jon Elster: Om Kapitalen. En studie i Karl Marx' hovedverk.
For $i$ virkeligheden har I fælles interesser: at få universitetet gjort til en arbejdsplads, hvor alle kan studere, hvad de lyster, under de betingelser, som skabes $i$ fællesskab. Bedst er det, hvis dine kammerater, som overværer eksamen, er informeret $i$ forvejen og kan støtte dig, hvis det viser sig at "Rossen" eller "Høghen" er af kaliber "Superross" eller "Vampyrhøgh". Så er et kristeligt ord fra kammeraterne på sin plads. Men hvis alt preller af og jeres arbejdsforhold iøvrigt er ringe, så er en institutbesættelse et godt middel, blot man ikke dermed tror at en samfundsomvæltning er nær.

Og husk at det er vigtigt at man på en forståelig måde gør rede for, hvorfor det er nødvendigt at foretage denne handling - $i$ et enkelt sprog, for kun få har læst Marx og Marcuse.

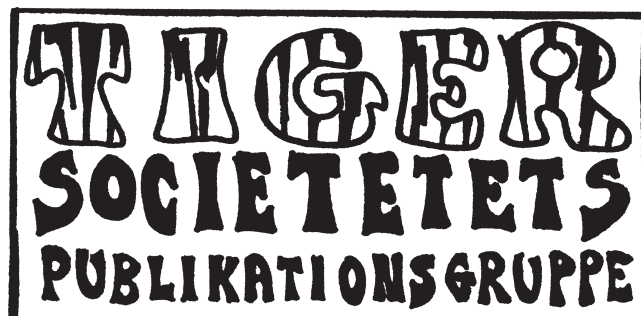

udgir str $\varnothing$ mme af sensationel læsning. Første udgivelse er bl.a. "Latinamerika og Imperialismen" i 2 bind.

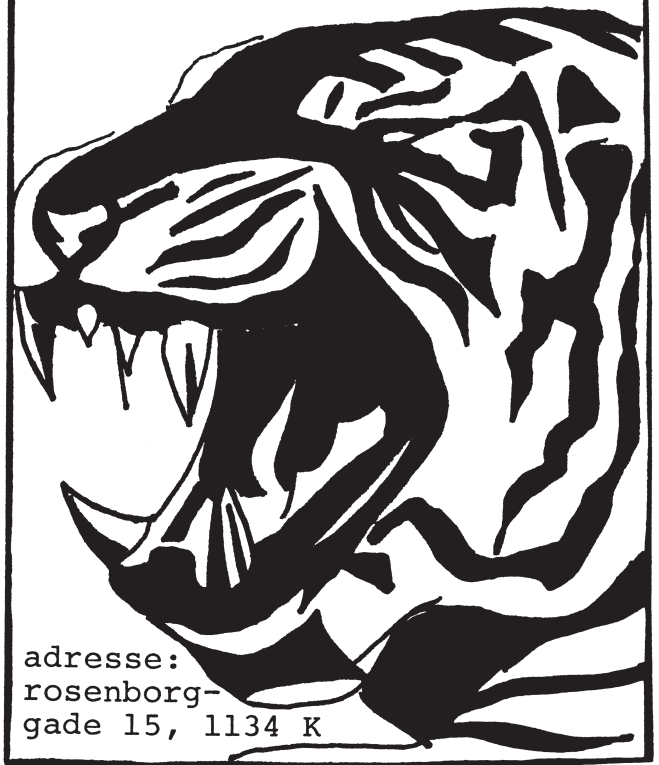

